\title{
Automated Preparation of Water Samples for Low-level Gamma Spectrometry
}

\author{
Marijan Nečemer* and Marko Gerbec \\ "Jožef Stefan”, Institute, Jamova 39, 1000 Ljubljana, Slovenia \\ * Corresponding author: E-mail: marijan.necemer@ijs.si
}

Received: 24-08-2015

\begin{abstract}
The analysis of water samples using gamma spectrometry requires the preconcentration of the sample in order to determine the content of low-level radionuclides. An automated evaporator was used for this purpose during the preparation of approximately 250 samples per year as part of the monitoring programmes performed in Slovenia. Since an automated sample-evaporation procedure has not yet been reported in the relevant literature, our unique, innovative, in-houseconstructed system is described in terms of developing the design, its optimization and automation.
\end{abstract}

Keywords: Water sample preparation, evaporation rate, optimization, radiological monitoring, radioactivity in water

\section{Introduction}

The national environmental radioactivity-monitoring programmes in the Republic of Slovenia and the Krško Nuclear Power Plant off-site radiological monitoring require control of the radioactivity in the air, ground and surface waters, precipitation, foodstuffs, soil as well as direct radiation. ${ }^{1}$ The samples collected as part of the annual programs of the radiological survey are sampled periodically, usually on a 2-week or monthly basis. The concentrations of the natural and artificial radionuclides in these samples are measured using high-resolution gamma spectrometry (HRGS), which is the method of choice because it is a fast, multi-nuclide method that is non-destructive as well as having good sensitivity and selectivity. ${ }^{2}$

Within the frame of the above-mentioned survey approximately 250 water samples per year were prepared and analysed in our laboratory, among them there were 24 rainwater, 60 water from waterworks and/or tap water, 15 drinking water, 20 surface water (rivers), 2 waste disposal, $\sim 100$ ground (geological) water, and $\sim 10$ samples from occasional customers (different sources of water). Since the radionuclide levels in such samples are low, it is common practice in radiochemistry for the liquid samples to be pre-concentrated in order to obtain sufficient sensitivity for the HRGS measurements. Thus, the sample preparation for the HRGS analysis involved the evaporation of 50 litres of water at $65^{\circ} \mathrm{C}$ to dryness. ${ }^{3}$ Since the evapo- ration step was time consuming and the number of samples per year was high, it was necessary for the pre-concentration step to be carried out with an automatic evaporation system under $65^{\circ} \mathrm{C}$, which was the maximum-allowable temperature in order to prevent the loss of volatile radionuclides from the sample, especially iodine, ${ }^{131} \mathrm{I} .{ }^{4}$

According to the literature, many studies have been performed on the behaviour of natural and man-made radionuclides in river, lake, sea, rain, drinking-water samples, etc., in the field of aquas geochemistry, ${ }^{5}$ radiation protection, ${ }^{6}$ health protection, ${ }^{7}$ etc. In general, the determination of low-level radionuclides (few $\mathrm{mBq}^{-1}$ ) in liquid samples was carried out by gamma or alpha spectrometry after various preconcentration procedures.

The volume of liquid sample applied in the investigations varied considerably (a few litres to 1000 1). For example, in the field of aquas geochemistry Blake et al. and Fairclough et al. collected 20-25 1 of lake water for $\mathrm{Ra}$ and Th determinations, ${ }^{8,9}$ Pampura et al. recognised that low levels of $U$ and $T h$ in river and lake waters make it necessary to take samples of up to $40-501 .^{10}$ Martin et al. analysed 30-50 1 of river and estuary waters for $\mathrm{U}$ radioisotopes in the Zaire estuary, ${ }^{11}$ Nozaki reported that the measurement of Th radioisotopes in seawater, especially the long-lived ones, requires samples of more than $100 \mathrm{l}$, due to their low abundance and activity. ${ }^{12}$

Generally, we can assume from the literature that around 20-25 1 of water is sufficient for a satisfactory analysis of uranium, radium and thorium isotopes in fresh, 
preconcentrated water samples, as described above, either by alpha or gamma spectrometry. Only for the analysis of $\mathrm{Ra}$ isotopes was a smaller volume, up to $10 \mathrm{l}$, required, meanwhile the determination of Th isotopes in some cases required a larger volume of water sample (up to $100 \mathrm{l}$ ). For radionuclide measurements, the major advantage of gamma spectrometry over alpha spectrometry was its simultaneous determination of several nuclides in a single counting stage (multi-nuclide capability). In contrast, alpha spectrometry requires complex and time-consuming separation and isolation procedures for the radionuclide of interest ( $\mathrm{U}$ or $\mathrm{Th}$ series radionuclides) involving a skilled radiochemist.

The evaporation preconcentration step was lengthy and performed mainly manually under IR light on up to 5-10 1 of sample. Larger amounts of sample were processed by coprecipitation or chemisorption on various types of resin. The evaporation step itself has not been discussed in the literature in detail and no investigations regarding the automation of an evaporation system for a larger volume of the above-mentioned samples has been reported yet, with the exception of Bandong et al., who proposed an automated system based on precipitation and chemisorption for the isolation of gamma-ray emitters from coastal waters. ${ }^{13}$

Furthermore, special attention with respect to water samples should be dedicated to the determination of the radioactivity in natural water samples $\left({ }^{238} \mathrm{U},{ }^{226} \mathrm{Ra},{ }^{228} \mathrm{Ra}\right.$, ${ }^{228} \mathrm{Th}$ ). According to European legislation, drinking water has to be monitored in order to protect the health of the general public, and future refinement of this legislation will require an improvement of the present analytical methods and the development of new, more sensitive and reliable analytical techniques based on a possible improvement of the evaporation process or precipitation and chemosorption to enable the determination of a few tens of $\mathrm{mBq} \mathrm{l}^{-1}$ of the above-mentioned radionuclides, ${ }^{7}$ which is one-order-of-magnitude lower than actually required.

According to all the above-mentioned facts, in our case the application of the combination of the innovative, unique, automated evaporation system and HRGS enables the analysis of a large diversity of water samples like rain, river, lake, natural water samples, waste water, etc. The simultaneous multi-nuclide capability of HRGS for the solid sample residue after evaporation enables a determination of the ${ }^{7} \mathrm{Be},{ }^{40} \mathrm{~K},{ }^{137} \mathrm{Cs},{ }^{210} \mathrm{~Pb},{ }^{22} \mathrm{Na},{ }^{131} \mathrm{I},{ }^{226} \mathrm{Ra},{ }^{228} \mathrm{Ra}$, ${ }^{238} \mathrm{U},{ }^{228} \mathrm{Th}$, depending on the type of sample, with the limit of detection from a few tens to a few $\mathrm{mBq}^{-1}$, and also in the case of waste liquid sample, analysis of the fission nuclides in was possible. Besides this, also the sensitivity of the analysis of ${ }^{90} \mathrm{Sr}$ by liquid scintilation counting (LSC) in the residue after HGRS analysis was improved. The evaporation volume of the sample could be flexible, depending on the customer's requirements, from a few 1 up to $100 \mathrm{l}$ or higher, as in the case of special investigations, which were frequently performed in aqueous geoc- hemistry. The automated evaporation system requires a minimum manpower for its operation, only for the installation of the sample barrel at the beginning of the evaporation process and the collection of the dry residue in its final stage. For example, the successful investigation of ${ }^{238} \mathrm{U}$ in ground-water samples using our proposed analytical procedure was reported by Korun and Kovačič. ${ }^{14}$

Since the evaporation step in the literature as mentioned above has not been described and discussed thoroughly, we would like in this paper to report in more detail our 27 years of experience in the construction, development and investigations of the automation of our unique and innovative evaporation system. The results reported in this work could improve knowledge about the evaporation sample preparation procedure and encourage the further popularization of the application of this undoubtedly valuable sample-preparation tool among potential users.

The evaporation system was a very simple, robust, semi-automatic device consisting of five evaporation chambers, a forced air-stream ventilation under the evaporation pan, sets of electromagnetic valves controlling the introduction of the sample from the barrel into the pan, its liquid level sensors and an IR heater. It was constructed in-house in 1988. The water sample was introduced into the evaporating pan (stainless steel with a Teflon coating inside, diameter $0.15 \mathrm{~m}$ ) from the elevated barrel by opening and closing the magnetic valve with an automatic controller, according to the pre-set minimum or maximum level of water in the pan. The evaporation was carried out with an infrared heater $(600 \mathrm{~W})$ placed above the surface of the water in the pan. The regulation of the electrical power of the heater with a potentiometer was not automatic regarding the temperature fluctuation of the water in the pan. It was adjusted manually, two times per day, based on the display reading of the simple digital thermometer in the pan. In order to facilitate the evaporation process, the pump was mounted in the system before the evaporation chambers, with the aim to ventilate the moist air produced by the evaporation process in the system. The incoming fresh air was, due to the vacuum in the system, entering through the central filter mounted in front of the pump and afterwards through five filters positioned under each evaporation chamber, with the aim to remove any possible dust and suspended particles from the air. For the overheating protection, two bimetal thermostats were installed under the evaporation chambers in the heating circuit if the temperature of the water or the exiting air exceeded pre-set values.

On the basis of almost two decades of experience with this system, we found that it was unreliable and also, due to the above-described insufficient monitoring of the temperature regulation of the evaporation process, there was a lack of sophisticated electronic regulation control for the system parameters, out of date and worn out hardware, direct personal control requirement, etc. For these 
reasons, we occasionally suffered a loss of sample due to over-pouring from the pan, overheating of the sample and, therefore, the possible loss of volatile radionuclides from the sample.

In 2003 our laboratory for HGRS received accreditation from the Slovenian Accreditation (SA) for the analysis of environmental samples, the main requirement for which is traceability and control through all the steps of the preparation procedure of the sample.

In order to overcome these problems and the drawbacks associated with the evaporation system and so as to fulfil the requirements of the ISO/IEC 17025 standard concerning traceability and the monitoring of each step of the evaporation process for the preparation of water samples, the old evaporation system was found to be inadequate. Our aim was to design, build and finally to operate an evaporation system (known as the evaporator) with the following characteristics:

- Automatic operation - the apparatus must operate continuously ( $24 \mathrm{~h}$ per day, 7 days per week) without any direct personnel control under the specified operating conditions.

- Regulated conditions - the relevant operating parameters (sample-evaporation temperature, air-stream velocity over its surface, and sample level in the evaporation pan) in each evaporation chamber must be within the prescribed limits.
- Optimization of the evaporation rate - the time required to concentrate the sample must be significantly reduced.

This paper presents our approach to the design of an improved evaporator system, a description of the constructed system, as well as the further optimization of its operation in terms of the operational parameters that affect the evaporation rate, i.e., the experimental results.

\section{Experimental}

\section{1. Design Approach}

The approach to the design of the improved evaporator system followed the operability analysis of the old one and various suggested solutions. The analysis is presented in Table 1.

In addition to the operability problems elaborated above, the parameters that affect the performance must also be considered. The evaporation of water is an important physical phenomenon that occurs in nature and is exploited in several industrial and engineering applications. Therefore, in all industrial systems it is necessary to have a good, predictive system for the evaporation rate as a function of the various parameters, e.g., the velocity of the gas streams, the water and air temperatures, the humidity, etc. The mass transfer of water into the humidity of the ambient air over large flat surfaces, e.g., pools, using a

Table 1. Summary of the operability analysis for the old evaporator system

\begin{tabular}{|c|c|c|c|}
\hline Problem & Cause & Consequence & Envisaged solution \\
\hline $\begin{array}{l}\text { Non-stable, semi-automatic } \\
\text { operation, temperature } \\
\text { fluctuations }\end{array}$ & $\begin{array}{l}\text { Manual set-up } \\
\text { of heater power - usually } \\
\text { twice per day }\end{array}$ & $\begin{array}{l}\text { Hard to regulate sample } \\
\text { temperature at } 65^{\circ} \mathrm{C}, \\
\text { can go above } 70^{\circ} \mathrm{C}\end{array}$ & $\begin{array}{l}\text { Regulate heater-plate power } \\
\text { to reach the desired temperature. } \\
\text { Additional sample and air } \\
\text { temperature high control? }\end{array}$ \\
\hline $\begin{array}{l}\text { Parameters in each } \\
\text { chamber had to follow }\end{array}$ & $\begin{array}{l}\text { Air flow and temperature } \\
\text { regulated only at the whole } \\
\text { evaporator system level }\end{array}$ & $\begin{array}{l}\text { Air flow rate low/high, leading } \\
\text { to slow evaporation, or sample } \\
\text { losses in a chamber(s) }\end{array}$ & $\begin{array}{l}\text { Air-flow-rate inlet valves for } \\
\text { each chamber. Heater power } \\
\text { regulator for each chamber. }\end{array}$ \\
\hline Occasional sample losses & $\begin{array}{l}\text { Air stream inside individual } \\
\text { chambers not optimized for the } \\
\text { high evaporation rate and the } \\
\text { absence of sample surface waves }\end{array}$ & $\begin{array}{l}\text { Slow evaporation or sample } \\
\text { spills out of the evaporation } \\
\text { pan (lost) }\end{array}$ & $\begin{array}{l}\text { Air duct/chamber inlet } \\
\text { gaps to be adjustable for } \\
\text { optimum performance }\end{array}$ \\
\hline $\begin{array}{l}\text { Occasional sample } \\
\text { cross-contamination }\end{array}$ & $\begin{array}{l}\text { Sample-delivery tubes are easy } \\
\text { to confuse for the five chambers } \\
\text { (the chambers are dedicated for } \\
\text { the anticipated sample activity) }\end{array}$ & $\begin{array}{l}\text { Contamination of sample } \\
\text { with other radionuclides }\end{array}$ & $\begin{array}{l}\text { Preparation and use of dedicated } \\
\text { colour-coded tubes and } \\
\text { accessories }\end{array}$ \\
\hline $\begin{array}{l}\text { Electronics in contact } \\
\text { with samples/water }\end{array}$ & $\begin{array}{l}\text { Control equipment located } \\
\text { below the level of the } \\
\text { chambers. }\end{array}$ & $\begin{array}{l}\text { Failures, repairs, delays, } \\
\text { personnel electrocution hazard }\end{array}$ & $\begin{array}{l}\text { Relocation of all the control } \\
\text { equipment above and behind } \\
\text { the level of the chambers }\end{array}$ \\
\hline Corrosion & $\begin{array}{l}\text { Occasional cleaning of } \\
\text { the evaporation pan with } \\
\text { acid }(\mathrm{pH}<2)\end{array}$ & $\begin{array}{l}\text { Corrosion of the level sensors, } \\
\text { cables and valves, failures, } \\
\text { delays }\end{array}$ & $\begin{array}{l}\text { Redesign using the } \\
\text { acid-resistant devices } \\
\text { and equipment (Inox, Teflon@ } \odot \text { ) }\end{array}$ \\
\hline $\begin{array}{l}\text { No process visualization } \\
\text { and auditing functionality }\end{array}$ & $\begin{array}{l}\text { No data logging in the } \\
\text { control system }\end{array}$ & $\begin{array}{l}\text { ISO/IEC } 17025 \text { requirements } \\
\text { not reached }\end{array}$ & $\begin{array}{l}\text { Data from programmable logic } \\
\text { controllers (PLCs) to be visible } \\
\text { and stored with dedicated } \\
\text { PC and its software. }\end{array}$ \\
\hline
\end{tabular}


correlation based on the analogy of heat and mass transfer reported by Shah $^{15}$ :

$$
S h=\frac{\boldsymbol{h}_{m} L}{D}=S c^{\frac{1}{3}}\left(0.036 R e^{0.8}-836\right)
$$

where

$$
S c=\frac{\mu}{\rho D} \text { and } \operatorname{Re}=\frac{v L \rho}{\mu}
$$

$S h, S c$ and $R e$ are the dimensionless Sherwood, Schmidt and Reynolds numbers, $h_{m}$ is the mass-transfer coefficient in the gas phase $(\mathrm{m} / \mathrm{s}), L$ is the water surface length in the direction of the air flow (m), and $D, \rho, \mu$ are the diffusivity of water in air $\left(\mathrm{m}^{2} / \mathrm{s}\right)$, the density of the air $\left(\mathrm{kg} / \mathrm{m}^{3}\right)$ and the viscosity $(\mathrm{kg} / \mathrm{m} \times \mathrm{s})$, respectively, and $v$ is the air speed over the surface of the water $(\mathrm{m} / \mathrm{s})$.

The equation was later modified to a number of more empirical equations by Asdrubali ${ }^{16}$ :

$$
E=\frac{\left(0.089+0.040782 v_{a}\right) A_{p} \Delta P}{Y}
$$

where $E$ is the evaporation rate $(\mathrm{kg} / \mathrm{h}), v_{a}$ is the air velocity parallel to the surface of the water $(\mathrm{m} / \mathrm{s}), A_{p}$ is the surface area of the water $\left(\mathrm{m}^{2}\right), \Delta P=P_{w}-P_{r}$ is the difference between the water saturation pressure and the room (ambient) water pressure $(\mathrm{Pa})$ and $Y$ is the latent heat of water vaporization for a given temperature (e.g., $2256.9 \mathrm{~kJ} / \mathrm{kg}$ at 100 $\left.{ }^{\circ} \mathrm{C}\right)$. The water saturation pressure is dependent on the temperature; the ambient air moving over the water surface has a water pressure that is dependent on its temperature and humidity. The Antoine ${ }^{17}$ equation (4) can be used here:

$$
\log _{10} P_{w}=A-\frac{B}{C-T}
$$

where $P_{w}$ is in $\mathrm{kPa}, T$ is in $\mathrm{K}, \mathrm{A}=16.5362, \mathrm{~B}=3985.44$ and $\mathrm{C}=-38.9974 .{ }^{18}$ The relative humidity is defined at a given temperature as:

$$
\phi=\frac{P_{r}}{P_{w}} 100 \%
$$

However, Eqs (1, 2 and 3) suggest that the evaporation rate is linearly related to the evaporation area available and the water-pressure difference in the air (the latter increases with the sample temperature), while the air speed is only linearly related to some extent - and also related to the actual water-pressure difference across the evaporation area.

Next, there is a practical question: what can be done in order to increase the evaporation rate, after taking into account all the other imposed limitations? The approach was as follows:
- Regarding the available area, rectangular porcelain ware evaporation pans with a size of about $0.25 \mathrm{~m} \times 0.31 \mathrm{~m} \times$ $0.055 \mathrm{~m}$ were selected (based on size availability and the similarity with previous pans).

- Regarding the required energy for the water evaporation, the samples were heated using electrical heaters located just below the pans.

- Regarding the maximum water-vapour pressure difference - a maximum sample temperature of about $65^{\circ} \mathrm{C}$ was selected; this was based on the question of the potential loss of volatile radionuclides from the sample. However, as shown later in Section 4, the evaporation rates for the other temperatures were also determined.

- In addition, the air flow over the sample surface must be maintained in order to keep the water pressure in the bulk low. This means that, in principle, the highest possible air-flow rate over the sample should be applied in a smooth way, and if possible a moderate interaction with the surface should be ensured. As will be shown in Section 4, a maximum air flow of about $60 \mathrm{~m}^{3} / \mathrm{h}$ at the temperature of the chamber could be applied without the excessive generation of waves, leading to sample spill-over from the edge of the pan (potential sample losses). This was ensured by the optimization of the airjet geometry from the input air distributor gap, as well as to the optimum sample height in the pan.

\section{2. General System Description}

The revised evaporation system is presented schematically in Fig. 1 with the chamber details (Fig.2), the air flow distributor geometry (Fig. 3) and photographs (Fig. 4, 5 and 6).

A functional description of the system apparatus, its regulation and process parameters are summarized in Table 2.

The operator starts the evaporation system at the control panel (PLC-6), while each chamber is operated by its own PLC (1-5) user interface. The latter consists of an initial sample feed into the chamber/pan (via valve EMV$\mathrm{X} 1)$, enabling the heater $(\mathrm{H}-\mathrm{X} 1)$ and opening the air input and output electro-magnetic valves (EMV-X2 and X3). The evaporation $\operatorname{pan}(\mathrm{s})$ operate until there are sample feed(s) from the sample vessel(s), after that the residue is dried to the end, which usually lasts for up to about $60 \mathrm{~h}$ for a 50-litre sample. After that the particular chamber cover is lifted (the chambers are under slight vacuum - see Table 2, row no. 6), the pan is removed for the sample to be taken out, the sample is subsequently analysed, and finally the pan is cleaned and prepared for the next sample.

The supporting air-circulation sub-system consists of rough and fine dust-particle filters at the inlet from the room with the evaporation system (this is to use the heat losses from the system operation for air pre-heating), an electrical heater for the air entering the chambers (including its thermal protection via temperature and air flow/pressure difference sensors (see Table 2, note c). 


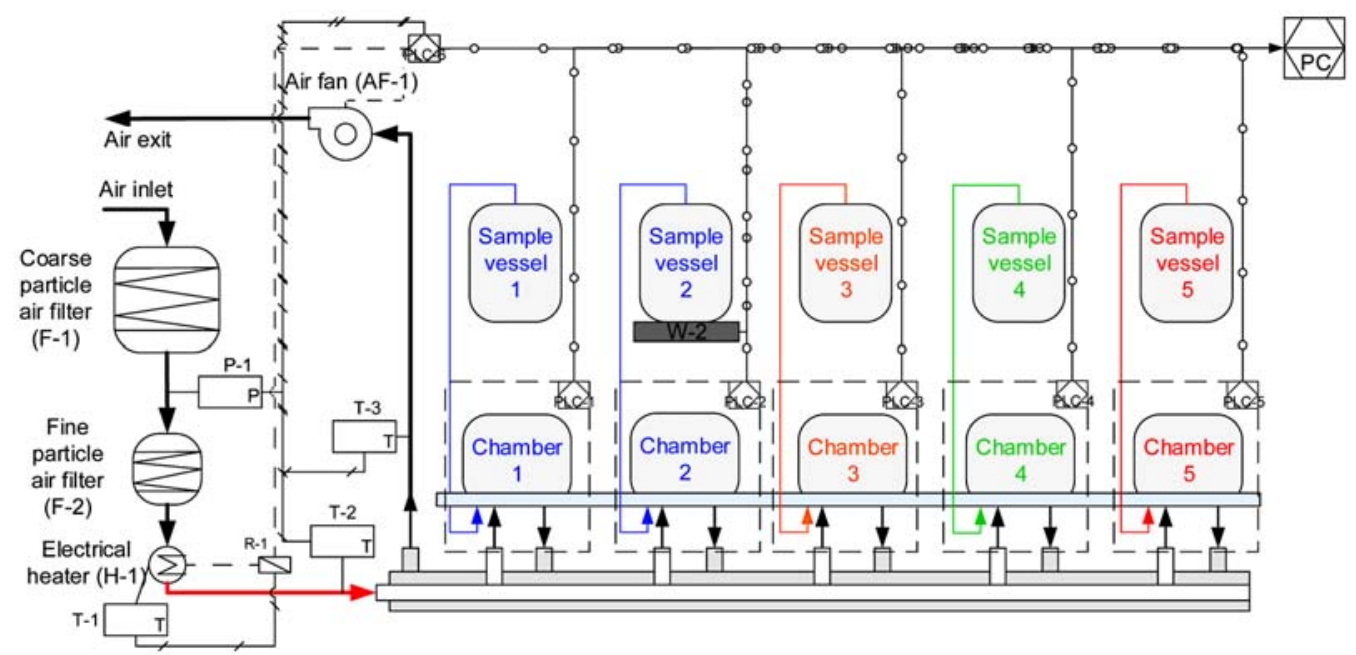

Figure 1. Schematic of the sample-evaporation apparatus. Details of the evaporation chambers (within dashed boxes) are shown in Fig. 2.

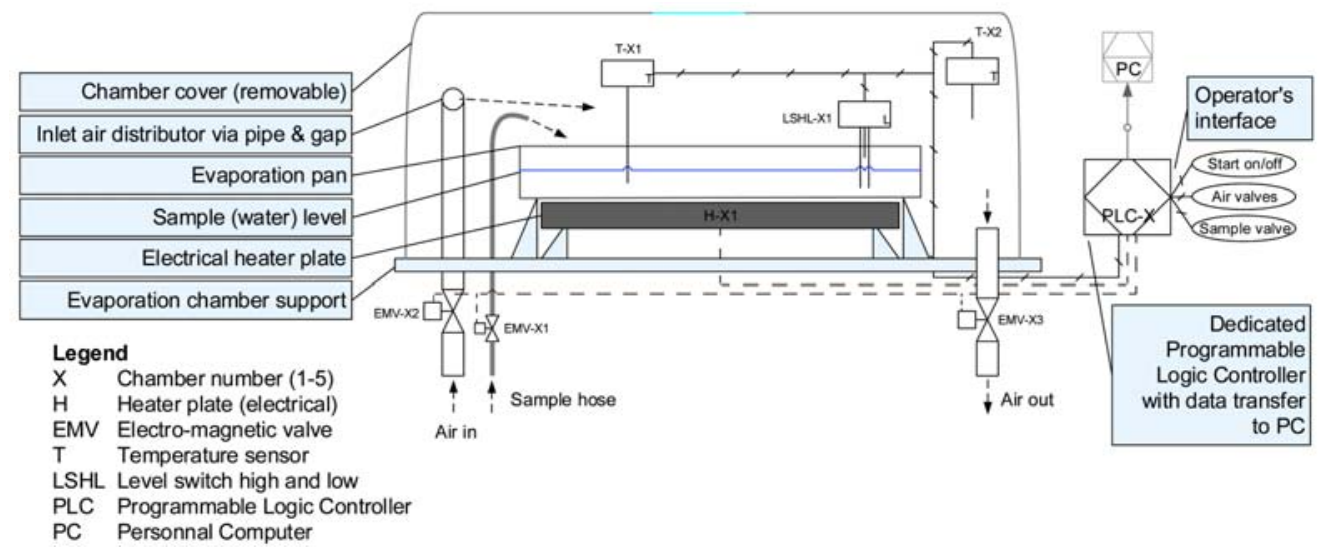

Figure 2. Schematic view of a single evaporation chamber

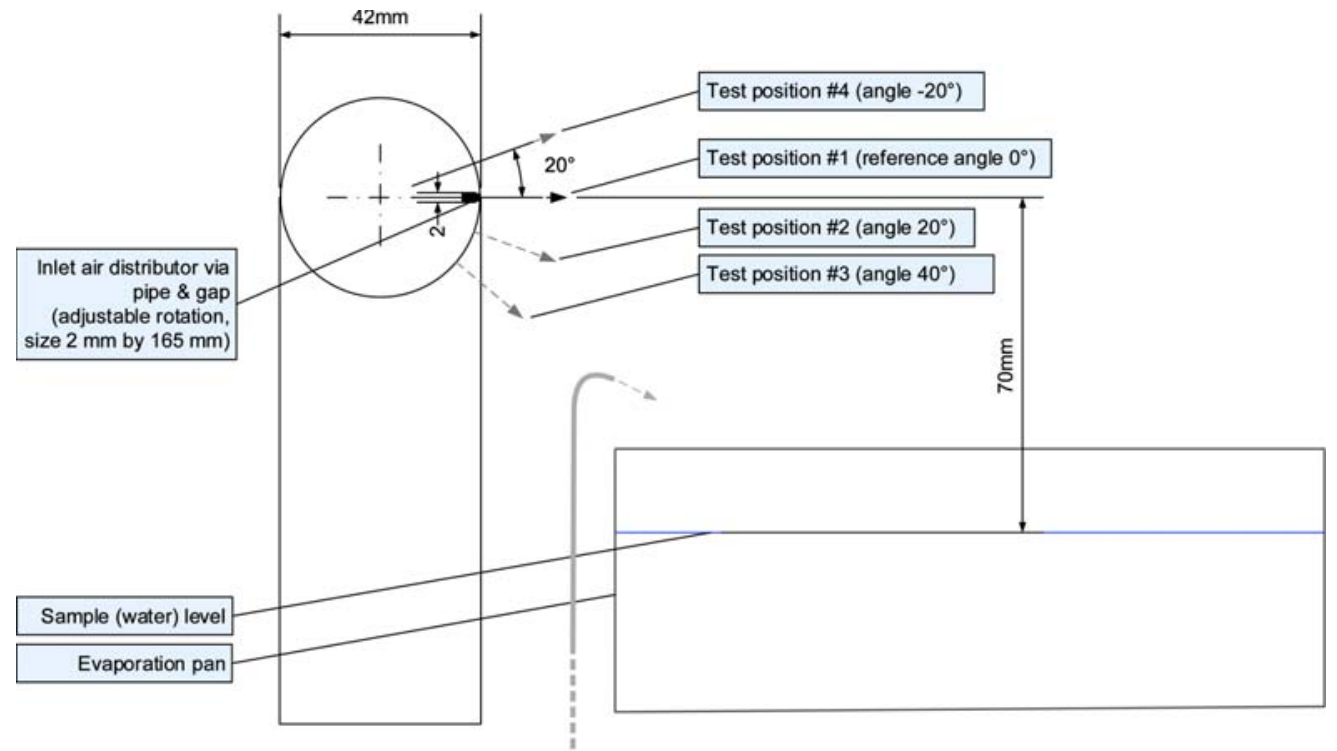

Figure 3. Detail of the inlet-air distributor gap and the position angles against the plane of the sample surface. 


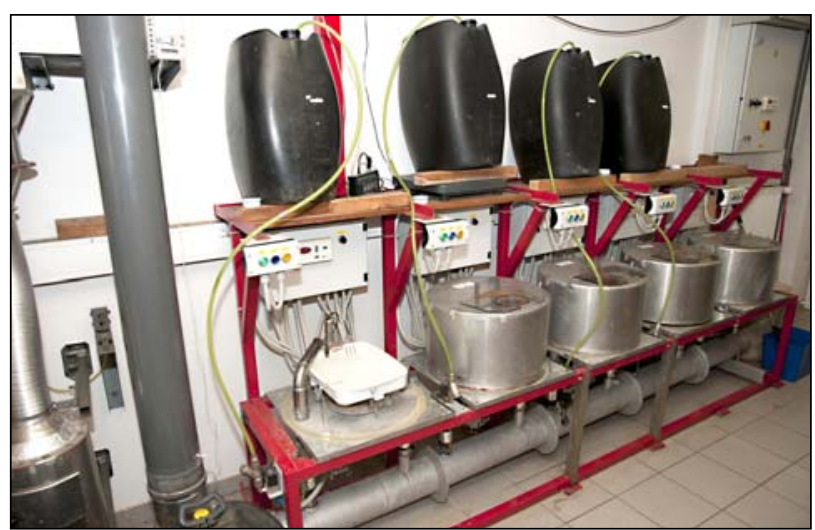

Figure 4. Photograph of the evaporation apparatus with the first chamber cover removed.

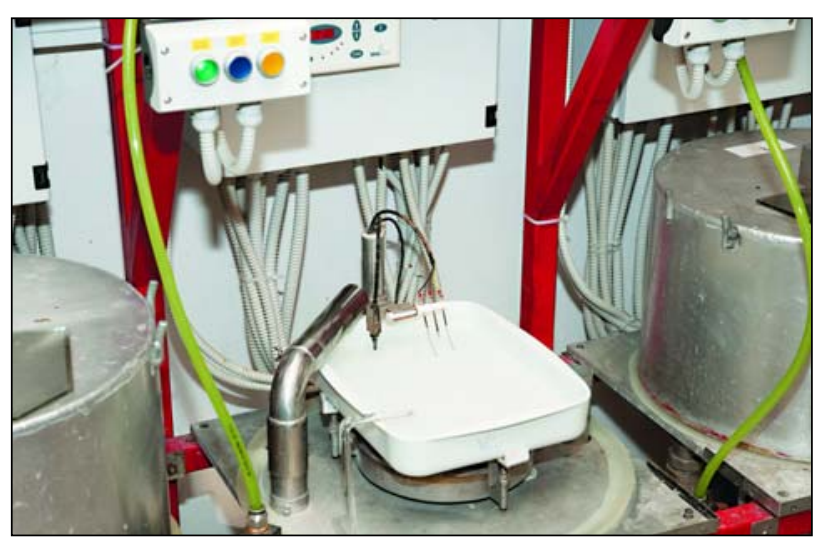

Figure 5. Photograph of the interior of the sample-evaporation chamber.

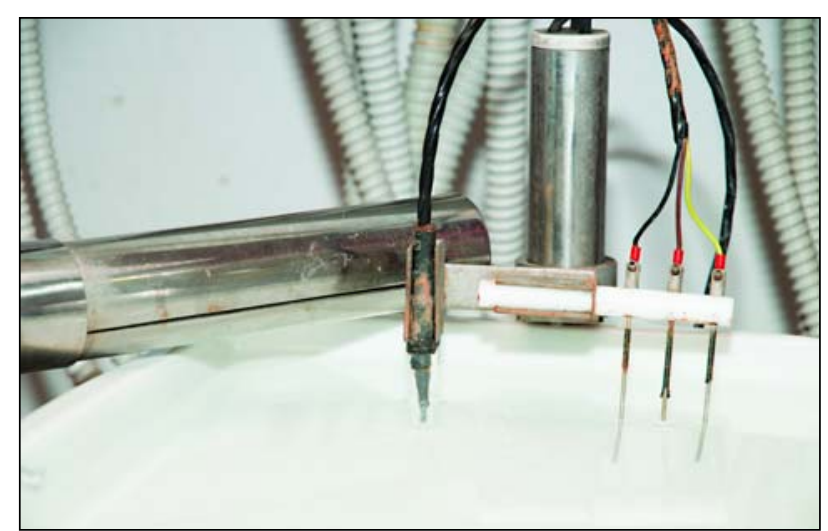

Figure 6. Photograph of the details of the sample-level sensor (right) and the temperature sensor (left) in the evaporation chamber.

In order to avoid cross contamination between samples, five sets of sample vessels, supply hoses, valves, chambers and evaporation pans are uniquely colour-coded according to which sort of water sample should be evaporated. Also, each evaporation chamber was constructed as a unique closed system, which means that possible cross contamination between the chambers was prevented (see Figure 1 and 4).

\section{Results and Discussion}

In addition to the design approach explained above and its implementation (General system description), the air flow inside the chambers was optimized by mea-

Table 2. Functional description of the regulation of the parameters for the evaporator apparatus

\begin{tabular}{|c|c|c|c|c|c|c|c|c|c|}
\hline \multirow[b]{2}{*}{ \# } & \multirow[b]{2}{*}{ Parameter } & \multirow[b]{2}{*}{ Unit } & \multicolumn{2}{|c|}{ Value } & \multirow[b]{2}{*}{ High } & \multirow[b]{2}{*}{ Sensor } & \multicolumn{2}{|r|}{ Regulation loop } & \multirow[b]{2}{*}{ Function } \\
\hline & & & Set & Low & & & Logic & Actuator & \\
\hline 1 & Sample temperature & ${ }^{\circ} \mathrm{C}$ & 65 & 60 & 70 & $\mathrm{~T}-\mathrm{X} 1$ & PLC-X & $\begin{array}{c}\mathrm{H}-\mathrm{X} 1 \\
\text { each chamber }\end{array}$ & Sample temperature in \\
\hline 2 & Chamber temperature & ${ }^{\circ} \mathrm{C}$ & 95 & / & l & $\mathrm{T}-\mathrm{X} 2$ & PLX-X & $\mathrm{H}-\mathrm{X} 1$ & $\begin{array}{l}\text { Chamber temperature } \\
\text { protection }\end{array}$ \\
\hline 3 & Sample level & $\mathrm{mm}$ & 35 & / & / & LSHL-X1 & PLC-X & EMV-X1 & Sample level in the chamber \\
\hline 4 & Air flow & l & On & / & / & operator & PLC-X & EMV-X2 \& X3 & $\begin{array}{l}\text { Air flow on/off in the } \\
\text { chamber }\end{array}$ \\
\hline 5 & Sample amount & $\mathrm{kg}$ & / & / & / & $\mathrm{W}-2^{\mathrm{a}}$ & operator & operator & Information for operator \\
\hline 6 & Air pressure difference & $\mathrm{Pa}$ & 3000 & I & I & $\mathrm{P}-1$ & PLC-6 & $\mathrm{AF}-1$ & $\begin{array}{l}\text { Assurance of air flow }{ }^{\mathrm{b}, \mathrm{c}} \text {, } \\
\text { information on F-1 \& F-2 } \\
\text { states }\end{array}$ \\
\hline 7 & Input air temperature & ${ }^{\circ} \mathrm{C}$ & 80 & & & $\mathrm{~T}-2$ & PLC-6 & $\mathrm{H}-1$ & $\begin{array}{l}\text { Regulate hot input air } \\
\text { temperature }\end{array}$ \\
\hline 8 & Output air temperature & ${ }^{\circ} \mathrm{C}$ & / & / & I & $\mathrm{T}-3$ & operator & operator & Information to operator \\
\hline 9 & Max. heater temperature & ${ }^{\circ} \mathrm{C}$ & 90 & I & I & $\mathrm{T}-1$ & $\mathrm{R}-1$ & $\mathrm{H}-1$ & $\begin{array}{l}\text { Heater max. temperature } \\
\text { protection }^{c}\end{array}$ \\
\hline
\end{tabular}

Notes:

$\mathrm{X}$ - Chamber number (1-5)

a - Implemented only for chamber \#2

b - Corresponds to about $60 \mathrm{~m}^{3} / \mathrm{h}$ per chamber (total $300 \mathrm{~m}^{3} / \mathrm{h}$ ) at T- $3=76{ }^{\circ} \mathrm{C}$

c - Criteria also for H-1 operation via PLC-6 and R-1 
suring the evaporation rate using the weigh gauge at chamber 2 and changing the related operational parameters:

- The sample set temperature was varied for the experimental tests, covering the range from 40 to $65^{\circ} \mathrm{C}(313 \mathrm{~K}$ to $338 \mathrm{~K}$ ).

- The air-flow distributor geometry was varied in terms of its gap angle relative to the parallel plane of the sample surface in the evaporation pan, covering the range from -20 to $40^{\circ}$ (for a graphical presentation see Fig. 3).

- The sample level set in the evaporation pan was varied in the range from 35 to $65 \mathrm{~mm}$, measured from the pan bottom.

As a reference situation the main operational parameters are summarized in Table 3 .

Table 3. Summary of the main operational parameters during the experimental optimization tests

\begin{tabular}{lcc}
\hline Parameter & Unit & Value \\
\hline Sample temperature in the pan & ${ }^{\circ} \mathrm{C}$ & 65 \\
Sample level in the pan & $\mathrm{mm}$ & 35 \\
Air-flow angle from the distributor gap & $\circ$ & 30 \\
Air-flow rate - chamber/system ${ }^{\mathrm{a}}$ & $\mathrm{m}^{3} / \mathrm{h}$ & $60 / 300$ \\
Air-inlet temperature - T-2 & ${ }^{\circ} \mathrm{C}$ & 80 \\
Air-outlet temperature - T-3 & ${ }^{\circ} \mathrm{C}$ & 76 \\
Air-inlet relative humidity ${ }^{\text {b }}$ & $\%$ & 4 \\
Air-outlet relative humidity $^{\mathrm{b}}$ & $\%$ & 14 \\
\hline
\end{tabular}

Notes:

a - Air fan AF-1 in operation and all the air valves for chambers 1-5 open

b - Approximate value from occasional measurements

The results suggest that the optimal evaporation conditions are at the highest temperature to which the samples can be exposed $\left(65^{\circ} \mathrm{C}\right)$, a sample level in the evaporation pan at $35 \mathrm{~mm}$ and an inlet-air distributor gap angle at about $30^{\circ}$ (according to the scheme in Fig. 3).

The validation of the evaporation process has also been performed by several experiments in order to determine the recovery of radionuclides present in our frequently analysed water samples. The investigations included comparison of results of radionuclides content (U-238, Th-234, Ra-226, Pb-210, Ra-228, Th-230, Th-228, K-40) presented in tap water and water samples with elevated concentrations of radionuclides from waste disposal-site of former uranium mine by our proposed method, alpha spectrometry after evaporation, K-40 via determination of $\mathrm{K}$ directly by atomic absorption spectrometry and determination of U-238 directly by inductively coupled plasma mass spectrometry. Besides this also determination of recoveries of man-made radionuclides (Co-57, Co-60, Sr-85, Y-88, Cd-109, Cs-137) in residue after the evaporation of a spiked solution in various media (tap water, distilled and mineral water) with multi-radionuclide CERCA (France) standard solution were carried

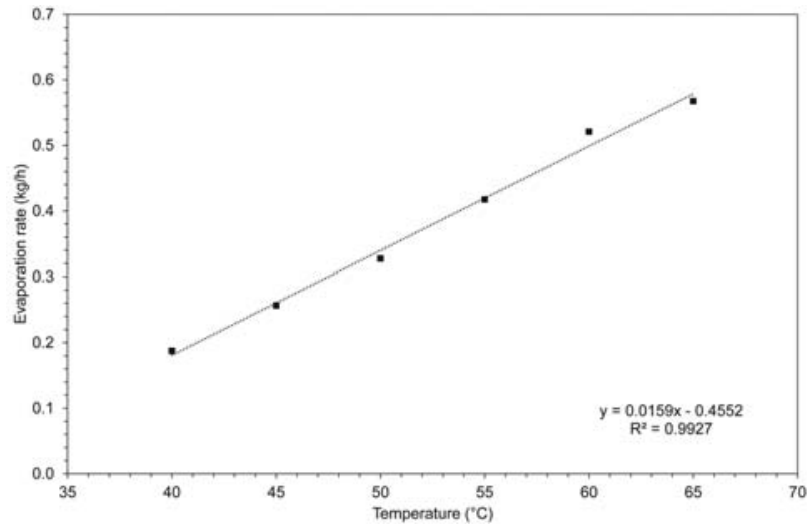

Figure 7. Graph of the sample evaporation rates at different sample temperatures in a chamber.

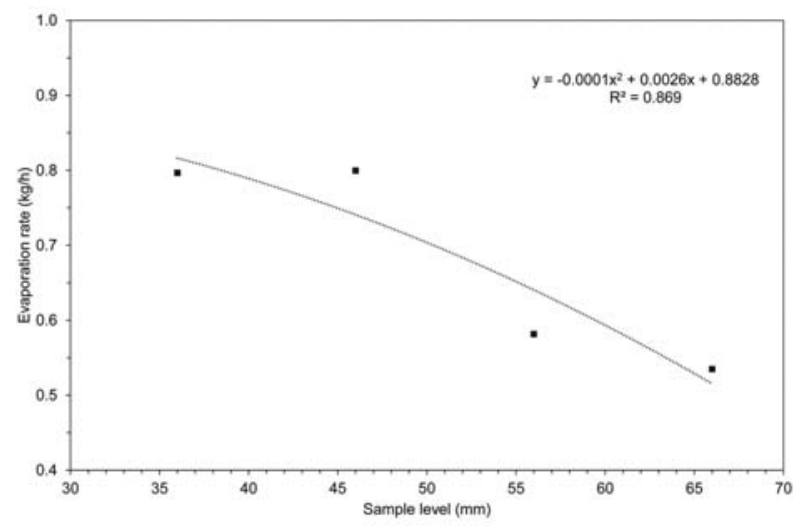

Figure 8. Graph of the sample evaporation rates at different sample levels in a chamber pan.

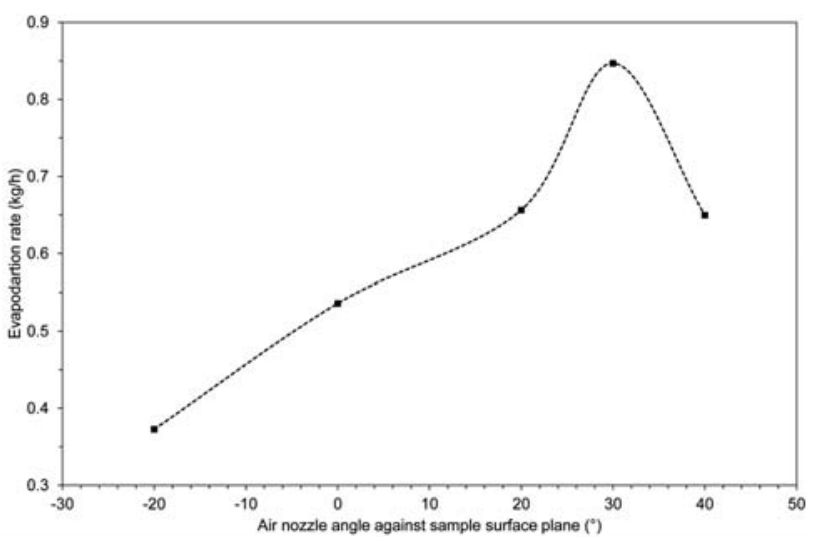

Figure 9. Graph of the sample evaporation rates at different inletair gap angles in a chamber.

out. The results obtained for the above-mentioned radionuclides analysed by various techniques were comparable with each other and confirm the suitability of the proposed evaporation procedure for routine applications. The recovery study of the artificial radionuclides was promising and found that their recoveries are mainly $90-100 \%$.

The aim of the proposed automated evaporation method is a pre-concentration of the large liquid sample 
(50 1) with minimal manpower required and a nondestructive determination of as many as possible radionuclides (at least 10) in the sample residue (few g) by gamma-ray spectrometry. It should serve mainly as a screening method for the non-stop processing of a larger number of samples, which also enable later specific separated analysis, such as alpha or beta emitters from the obtained residue by alpha or beta spectrometry if such is required. On the other hand, it is true that much simpler methods exist, such as precipitation, but it is a specific reaction and enables only preconcentration of a certain limited number of radionuclides from the sample. (e.g., Ra series on $\mathrm{BaSO}_{4}, \mathrm{U}$ or Th radioisotopes on $\mathrm{Fe}(\mathrm{OH})_{3}, \mathrm{Po}$ and $\mathrm{Pb}$ on $\mathrm{MnO}_{2}$ ). To perform this operation a skilled radiochemist is required.

The sample preparation by extraction of radionuclides using a strongly acid resin from the liquid sample could be a good alternative. But again, various radionuclides due to their specific chemical characteristic adsorb under specific conditions $(\mathrm{pH})$ on the cationic or anionic resin. In order to achieve the same results concerning the number of radionuclides as with our method, probably the combination of cationic and anionic exchange columns should be suitable and also a skilled radiochemist is required to perform such a complex procedure as well. On the other hand, our method also enables the preconcentration of artificial radionuclides, in contrast to their extraction on ion-exchange resin probably requires the application of a specific sort of resin.

As was already mentioned, the proposed technique was developed mainly for gamma-ray spectrometric measurements. It is true that it is possible to have a direct measurement of ion-exchange resin after so-called cleaning of the sample. But in the case of radioactive elements it is necessary to take into account their decay and the ingrowth in resins. This is very important in the case of a determination of Ra-226. The possible losses and different chemical properties of radionuclides of interest led to incorrect results.

The proposed automated evaporation procedure is a universal multi-radionuclide preconcentration method of natural and artificial origin in various types of liquid samples. It is a simple procedure, with minimal manpower and radiochemical knowledge of operator required, and serves as an ideal screening tool in combination with gamma spectrometry for a determination of the radioactivity of liquid samples and is especially suitable in various monitoring programmes, where the non-stop preparation of a larger number of samples is required. The main drawback is that that the method requires a semi-industrial automated system built in house and is not commercially available. On the other hand, alternative, frequently used radionuclide-preconcentration methods for liquid samples like precipitation, separation with ion-exchange column etc. enable isolation only of specific radionuclide or its series from the water sample.

\section{Conclusions}

An unreliable, old, sample-evaporation system was successfully replaced with a new one. The whole system was completely redesigned, reconstructed with added automatic regulations and its performance optimized. All the details of the evaporation process for each chamber can be documented on a PC, which allows auditing of the evaporation process. This completely fulfilled the metrological requirements and the new system allows further investigations of other important evaporation parameters responsible for the evaporation rate.

The typical sample evaporation time was reduced from approximately 100 hours to approximately 60 hours (50 litres to dry residue), the sample cross-contamination hazard and the sample quality (potential losses or thermal overtreatment) are now much better controlled and auditable. While the air stream inside the evaporation chambers was optimized in a number of experimental tests, potentially, at least, it could be further optimized in the future in terms of a closer air distributor tube and the gap to the sample surface over the whole pan width.

The data and results presented here are important for research laboratories that deal with measuring the concentration of radionuclides in water samples.

\section{Acknowledgements}

The authors want to express their thanks for help with the experimental work and the sample preparation to Dr. Benjamin Zorko, Mrs. Helena Fajfar and Mr. Drago Brodnik. For designing, constructing and automating the new evaporator system, we would like to express special gratitude to Mr. Bojan Černač.

\section{References}

1. B. Črnič, M. Korun, B. Zorko, Interpretation of radionuclide concentrations near the detection limit for dose calculations: $3^{\text {th }}$ European IRPA Congress, Radiation Protection - Science, Safety and Security (proceedings), Helsinki, Finland, 2010.

2. M. Stepišnik, B. Zorko, D. Glavič Cindro, Public Health Risk Assessment in the vicinity of the NPP Krško (1st edition), Institut Jožef Stefan, Ljubljana, 2011.

3. T. Petrovič, M. Lipoglavšek, B. Zorko, M. Nečemer, M. Korun, J. Radioanal. Nucl. Chem. 2010, 286, 423-427.

http://dx.doi.org/10.1007/s10967-010-0722-2

4. M. Korun, Appl. Radiat. Isot. 2008, 66, 841-844. http://dx.doi.org/10.1016/j.apradiso.2008.02.024

5. D. S. Moon, W. C. Burnett, S. Nour, P. Horwitz, A. Bond, Appl. Radiat. Isot. 2003,59, 255-262.

http://dx.doi.org/10.1016/S0969-8043(03)00193-3

6. M. Jungck, J. L. Andrey, P. Froidevaux, J. Environ. Radioact. 
2009, 100, 361-365.

http://dx.doi.org/10.1016/j.jenvrad.2009.01.006

7. M. Vasile, L. Benedik, T. Altzitzoglou, Y. Spasova, U. Wätjen, R. González de Orduña, M. Hult, M. Beyermann, I. Mihalcea, Appl. Radiat. Isot. 2010, 68, 1236-1239. http://dx.doi.org/10.1016/j.apradiso.2009.11.018

8. W. H. Blake, A. J. Plater, J. F. Boyle, J. Paleolimnol. 1998, 20, 1-14. http://dx.doi.org/10.1023/A:1007959824894

9. A. J. Fairclough, Unsupported ${ }^{226}$ Ra Chronology Halocene Lake Systems. Ph. D. Thesis, University of Liverpool, 1999.

10. V. D. Pampura, I. V. Sandimirov, I. S. Lomonosov, A. Y. Gapon, Y. I. Ulybusheva, A. G. Arsentiyeva, G. I. Popovskaya, Geochem. Int. 1996, 33, 90-103.

11. J. M. Martin, M. Meybeck, M. Pusset, Netherlands J. Sea Res. 1978, 12, 338-344.

http://dx.doi.org/10.1016/0077-7579(78)90036-4
12. Y. Nozaki, H. S. Yang, M. Yamada, J. Geophys. Res. 1987, 92(C1), 772-778. http://dx.doi.org/10.1029/JC092iC01p00772

13. B. B. Bandong, A. M.Volpe, B. K. Esser, G. M. Bianchini, 2001. Appl. Radiat. Isot. 2001, 55, 653-665. http://dx.doi.org/10.1016/S0969-8043(01)00081-1

14. M. Korun, K. Kovačič, Appl. Radiat. Isot. 2011, 69, 636640. http://dx.doi.org/10.1016/j.apradiso.2010.12.010

15. M. M. Shah, 2012. Calculation of evaporation from indoor swimming pools: Further development of formulas: ASHRAE Trans. 2012, 118, 460-466.

16. F. Asdrubali, Energy Build.2009, 41, 311-319. http://dx.doi.org/10.1016/j.enbuild.2008.10.001

17. C. Antoine, Comptes Rendus des Séances l'Académie des Sci. 1888, 107, 681-684, 778-780, 836-837.

18. G. V. Reklaitis, Introduction to Material and Energy Balances. Wiley, New York, 1983, pp. 649-652.

\section{Povzetek}

Analiza vzorcev vod s spektrometrijo gama terja prekoncentracijo vzorca, da lahko določimo nizko vsebnost radionuklidov v njih. Za ta namen uporabljamo avtomatiziran izparilnik, ki nam omogoča pripravo približno 250 vzorcev letno, v okviru različnih monitoring programov, ki se izvajajo v Sloveniji. Postopek priprave vzorca z avtomatiziranim izparjevalnikom do sedaj še ni bil objavljen v literaturi, zato v tem prispevku predstavljamo naš izviren in inovativen izparilni sistem, ki je rezultat domačega znanja. Opisan je razvoj zasnove in konstrukcije izparilnika, njegova optimizacija in način avtomatizacije. 